\title{
THE REJECTION OF FALSTAFF
}

\author{
Juan José Torres Núñez. Universidad de Almería
}

\begin{abstract}
This article discusses the rejection of Falstaff comparing Act 5, scene 5 of 2 Henry IV, with Act 1, scene 2 of 1 Henry IV.

The rejection is inevitable because Falstaff represents disorder. His triumph would mean the victory of anarchy over order, stability and justice. But we become so involved with him that we even tolerate his conspiracies. He is clever, funny and one of the most fascinating characters in English literature.

The two plays show the Prince as a good student of Machiavelli; we could consider them as a practical guide to instruct the Prince in his road to power.
\end{abstract}

\section{THE REJECTION OF FALSTAFF}

As Stephen Greenblatt points out, "the rejection of Falstaff has been one of the nagging 'problems' of Shakespearean criticism" (Dollimore \& Sinfield, 1994: 41). Perharps a good way of looking at the rejection of Falstaff would be to try to compare Act 5, scene 5 of 2 Henry IV, with Act 1, scene 2 of 1 Henry IV. This is the purpose of the present article.

To believe that the rejection of Falstaff in 2 Henry $I V(5.5)$ is unexpected, is the same as to say that we have not read carefully 1 Henry $I V(1.2)$. Yet, when we read 5.5, we cannot help the feeling of disappointment and sadness. We pity Falstaff to the point that we experience a sense of loss. We know that the King's words are the end of him:

I know thee not, old man. Fall to thy prayers.

How ill white hairs becomes a fool and jester!

I have long dreamt of such a kind of man,

So surfeit-swelled, so old, and so profane,

But, being awaked, I do despise my dream.

At this moment Falstaff does not understand the metamorphosis that the King has gone through, but we do. This is why the irony of the lines makes a painful reading. The pathos remains until the end of the scene and the end of the play. Actually, this metamorphosis is only 
a show for the public. If we read carefully the soliloquy of Prince Hal, 1.2, the first time he and Falstaff appear in 1 Henry $I V$, we realize that the Prince is a cold and calculating character. From this moment on he is embarked on a calculated and dishonest friendship. Then, if in 1.2 the Prince tells us his true intentions, why does 5.5 arouse in us so much pity? Let us analyse his words.

I know you all, and will awhile uphold The unyoked humour of your idleness.

Yet herein will I imitate the sun, Who doth permit the base contagious clouds To smother up his beauty from the world, That, when he please again to be himself, Being wanted, he may be more wondered at By braeking through the foul and the ugly mists

So when this loose behaviour I throw off ... shall I falsify men's hopes;

My reformation, glitt'ring o'er my fault

Shall show more goodly and attract more eyes

Than that which hath no foil to set it off.

$(1.2 .173-193)$

In this soliloquy we have all the information about Hal's future reformation. The lines show that the rejection has been calculated from the beginning. With an air of superiority he compares himself to the royal symbol, the sun. And thinking that his companions are diseasecarrying clouds and ugly mists, he treats them with haughty disdain. But the comparison implies that he has to use their baseness so that his reformation will glitter and attract the atention of his people when he throws off his loose behaviour.

From the very moment that Falstaff and Hal appear together, we see that Hal knows him and the rest of the cutpurses. Hal does not approve of them, yet he seeks their company. In this first encounter we learn that Falstaff has a lot of confidence in his sweet Hal and enjoys his company. But Prince Hal is clearly a man who can "falsify men's hopes". Therefore, Hal seems to be the false person of the two; False-staff, on the other hand, remains unchanged and true, at least to himself. However, knowing from the soliloquy that the whole thing is planned, we still feel pity and sorrow when Falstaff is rejected. Then, if we know what is going to happen, what is the reason for this grief?

When we study Hal and Falstaff in both plays, we tend to judge them with a double vision of life: what we should be, and what we actually are. Of course, this contrast is not really as neat as we would like it to be. But this double vision produces in us two kinds of response, and here seems to lie the complexity of judging the rejection. Our first response is objective. We follow Shakespeare in his presentation of the need for the political and moral order of the state in both plays and in Henry $V$. If we believe that "Shakespeare's plays are centrally and repeatedly concerned with the production and containment of subversion and disorder" (Dollimore \& Sinfield, 1994: 29) and that "the horror of social disorder runs throughout Shakespeare's canon" (Elsom, 1989: 140), then, Falstaff has to be rejected for the simple reason that he represents a threat to the order of the state and to monarchy. Prince Hal's words seem to be appropriate,

Odisea, $n^{0} 1,2001$ 
... I banish thee, on pain of death,

As I have done the rest of my misleaders,

Not to come near our person by ten mile,

$(5.5 .62-64)$

With these words the Prince wants to bring order to a corrupt society.

At this point it is important to keep in mind

the idea of order that constantly makes its claim, most insistently in the history plays. Scholars have observed the presence in Shakespeare's works of the so called Tudor myth ... Shakespeare may, for all we know, have personally subscribed to its premises -but a closer scrutiny of his plays has disclosed so many ironic reservations and qualifications and subvertions as to call into question any straightforward adherence to a political line. The plays manifest a profound fascination with the monarchy and with the ambitions of the aristocracy, but the fascination is never simply endorsement... The idea of order, though eloquently articulated ... is always shadowed by a relentless spirit of irony. (Greenblatt, 1997: 61)

1 Henry IV, 2 Henry and Henry $V$ appear "to ratify the established order, with the newcrowned Henry V merging his body into 'the great body of our state' [and] with Falstaff dispised and rejected" (Dollimore \& Sinfield, 1994: 41), although it could be argued that "the Henry IV plays, far from celebrating the monarchy, [they generate] subversive religious, social, and political idiologies, at least from the perspective of the advocates of order" (Howard \& O’Connor, 1987: 36).

But, perhaps on emotional grounds, we consider the rejection too severe and excessive. Objectively, as we have said, Falstaff is rejected because he represents disorder. His triumph would mean the victory of anarchy over order and stability. And if the play is concerned with order, it is obvious that anarchy has to be destroyed. Falstaff's triumph would bring about the annihilation of Justice. We see this in Falstaff's reaction to the King's death in 2 Henry IV:

Boot, boot Master Shalow! I know the young King is sick for me. Let us take any man's horses -the laws of England are at my commandment. Blessed are they that have been my friends, and woe to my Lord Chief Justice.

The woe here is not to the man, the Lord Justice, but to the justice of the land, the justice of the whole nation. England is a diseased and infected country, full of rebellion, aggression, betrayal, contention; it is a "poor kingdom, sick with civil blows". We can imagine Falstaff with the laws of England at his "commandment" governing the country as if it were the Gad's Hill Land. Falstaff would be like a lion preying on every living thing in a Darwinian world where justice would be the survival of the fittest. The security of living in this land would be the same as the pilgrims' chances of going safely to Canterbury. As Poins says in 1 Henry IV:

But my lads, my lads, tomorrow morning by four o'clock early, at Gad's Hill, there are pilgrims going to Canterbury with rich offerings, and traders riding to London with fat purses. I have visors for you; you have horses for yourselves. Gadshill lies tonight in Rochester. I have bespoke supper tomorrow night in Eastcheap. We may do it as secure as sleep. 
In 1.2, after the dialogue between Hal and Falstaff about whether thieves will be hanged in England when Hal becomes King, Falstaff says that he will be "a brave judge". But he is already judging "false", as Prince Hal retorts. The passage just quoted shows the truth of this falseness. Falstaff's justice has to be studied in terms of what Pistol says immediately after the word Justice in 2 Henry IV:

Let vultures vile seize on his lungs also! "Where is the life that late I led?" say they. Why, here it is. Welcome these pleasant days!

These lines tell us that vultures will seize the land and devour justice. Scene 5.3 seems to be a necessary introduction to scene 5.5.45 ("I know thee not..."), so that when we judge the rejection of Falstaff we already know the kind of government that we would have. The juxtaposition of the words "justice" and "vultures", together with these scenes (5.3 and 5.5), give us a picture that speaks by itself. In this kind of government tyranny would prevail over reason. To live in Falstaff's world, however beautiful, would mean to be constantly drunk with sherry. His actions would lead Gad's Hill Land to a world of revenge and favour. In 2 Henry IV he says:

Stand here by me, Master Robert Shallow. I will make the King make you grace

And later, Pistol says:

Rouse up revenge from ebon den with fell Aleto's snakes, for Doll is in. Pistol speaks nought but truth.

Falstaff's answer to all this is: "I will deliver her" (5.5.37). Certainly, this is a land of favouritism and revenge. And since this cannot be justified, before we read these lines in 5.5, 5.3 serves as a short introduction to show us that people have to be brought to justice.

So far, in our argument we have tried to explain and to rationalize the rejection of Falstaff from an objective point of view. Why, then, do we think that this rejection is excessive? Why do we love Falstaff so much? Perhaps the only possible explanation is that in this double vision that we have mentioned, there is a second response that is subjective. And this kind of response claims for mercy and charity. Throughout the two plays, we have been too emotionally engaged with a most lovable villain. He is clever, funny and one of the most fascinating characters in English literature, to the point that "Falstaff has led a life independent of the plays for which he was created" (Wells, 1995: 143). We become so involved with Fastaff that we even tolerate his conspiracies. Of course, this involvement is not a mere coincidence. First of all, Fastaff is an appealing character. He is not a hypocrite like Hal. To us, Hal is a person who will have majesty but not grace, as Falstaff reminds us in 1 Henry IV:

And I prithee, seweet wag, when thou are a king, as, God save thy grace -majesty I should say, for grace thou wilt have none- 
Prince Hal looks for the attraction and recognition of his own people. To do this, he needs the help of his tavern mates. He needs -he thinks- a "loose behaviour", so that once he throws it off, "[his] reformation, glitt'ring o'er [his] fault/Shall show more goodly and attract more eyes"

$$
\text { (1.2.191-19). }
$$

Falstaff is a villain, a knave and a rascal, but he is, above all, honest to his principles, however dubious they may be. He thinks "'tis no sin for a man to labour in his vocation". The double-sinner is rather Hal; he uses his friend for the purpose of gaining fame, grandeur and glory when his reformation glitters over his sins and past misdeeds. For this reason, it seems ridiculous to say that the Old Man is the "tutor and the feeder of [his] riots". He is no less corrupted than Falstaff. It is hard for us to believe that Falstaff is an ugly old devil trying to corrupt a beautiful young lamb. The lamb is as wicked and full of cunning as Falstaff. Falstaff is what he is, while Hal is what he is not. And this is perhaps the main message of the soliloquy of Act 1, scene 2 (1 Henry IV). In this scene we see signs of trouble ahead. The language shows the turmoil. Hal is inheriting the crown that his father, Henry IV, seized from Richard II. His father is responsible for the deposition and death of King Richard. Hal is, then, the son of a usurper.

The plays show a world of Machiavellian politics. Some critics find Hal a good student of Machiavelli. Refering to the soliloquy (1.2), Jean E. Howards points out that

In his sophisticated manipulation of power, Hal shows himself a good student of Machiavelli, and the Machiavellian strand of his characterization has caused a split in critical assessments of him. (Greenblatt, 1997: 1150)

The two plays could be considered as a practical guide to instruct the Prince in his road to power. He uses Falstaff and the rest of the tavern mates to learn the skills that will help him to become a successful King. He wants to become a shrewd and powerful politician with the help of his companions. The Prince, with his wicked ways, could corrupt a saint, as Falstaff says:

$\mathrm{O}$, thou hast damnable iteration, and art indeed able to corrupt a saint. Thou hast done much harm upon me, Hal -God forgive thee for it. Before I knew, Hal, I knew nothing; and now am I, if a man should speak trully, little better than one of the wicked.

$(1.2 .80-84)$

In this dialogue between Hal and Falstaff the exchange of words is witty and even ironic, with a lot of mockery, but we could ask ourselves who is indeed the most corrupted of the two.

Another reason for liking Falstaff is that he remains a child throughout the two plays, even at the moment of his death, dying "like an innocent child". And this, too, is why we tolerate his behaviour, in the same way that we tolerate children's misdemeanours. We simply feel more tolerance.

It is true that the rejection is not completely heartless, and the King provides Falstaff and his companions with an "advancement" so that "lack of means enforce [them] not to evils". But Hal fails to understand that an old man needs love more than physical comfort. Here we lose faith in the man that is going to be the King of England. We do not like the tone of the language 
he uses in 5.5.45-69. He hurts Falstaff. In fact, he precipitates his death, as we learn from the Hostess in Henry V:

By my troth, he'll yield the crow a pudding one of these days. The King has killed his heart.

Falstaff does not die like a poor villain. There is tenderness in the way Shakespeare describes his death. And this reinforces his importance in the play. We feel sorrow and pity for him. The Hostess assures us that "he's not in hell" and she "saw him fumble with the sheets, and play with flowers, and smile upon his finger's end... [She] put [her] hand into bed, and felt them, and they were as cold as any stone. Then [she] felt to his knees and so upwards, and upwards, and all was as cold as any stone" (Henry $V$, 2.3.8-20).

The feeling of coldness in this moving scene is the same coldness that we experience when the Prince calls Falstaff a "vain man", a fool with "white hairs". His death is not the death of a common villain, it is the death of an intelligent knave who represents the energy and force of natural desires and instincts. Falstaff knows that his way of life cannot be an example for the world to follow. He believes that the Prince's words in 2 Henry IV are only a pretence:

That can hardly be, Master Shallow. Do not you grieve at this. I shall be sent for in private to him. Look you, he must seem thus to the world.

The world cannot survive with Falstaff's philosophy of life, and yet, he will not change or let anyone interfere with his own life. When he realizes the true situation after the Chief Justice enters, he is stunned. "My Lord, my Lord" are his last words. This is the end of his "fortune", and from now on "torment" will accelerate his death.

Falstaff is uncontrollable like our dreams. He is all life and joy, sack and lechery; and he is irrational like our subconscience. But with all that, we cannot help the feeling of nostalgia for his world, probably best summarized in Silence's song. The song is Falstaff's Eden. And there we

Do nothing but eat, and make good cheer

And praise God for the merry year,

When flesh is cheap and females dear,

And lusty lads roam here and there so merrily,

And ever among so merrily.

What we have here is a true paradise. It is a true Garden of Eden where we do nothing but to enjoy the pleasures of life. However, Falstaff's world fails, not because we do not want it or like it, but because it cannot resist the impinging forces of anarchy to which it is exposed. This is the weakness of his world and this is the reason why he has to be rejected. According to Stanley Wells (1995: 145), "we have to sympathize with the Prince's inevitable rejection of [Falstaff's] values". We agree, but we do not forget that "Falstaff raised ideological qualms on social and political grounds" (Howar \& O'connor, 1987: 36). Our objective response is that the rejection is justified, but we cannot help feeling nostalgia for Falstaff's merry world of sack and wenches. A world that has no access to us because its anarchy and freedom cannot bring any amendments to the conflicts, disorder and injustice of our own world. 


\section{REFERENCES}

Dollimore, J. y Sinfield, A. eds. 1994. Political Shakespeare. Manchester: Manchester University Press.

Elsom, J., ed. 1989. Is Shakespeare Still Our Contemporary? New York and London: Routledge.

Greenblatt, S., ed. 1997. The Norton Shakespeare. New York and London: Norton.

Howard, J.E. y M.F. O’Connor, eds. 1987. Shakespeare Reproduced. New York and London: Routledge.

Wells, S. 1995. Shakespeare: A Life in Drama. New York and London: Norton. 